Summer 2009

\title{
Defragmentation of Public International Law Through Interpretation: A Methodological Proposal
}

Anne van Aaken

University of St. Gallen

Follow this and additional works at: https://www.repository.law.indiana.edu/ijgls

Part of the Constitutional Law Commons, International Law Commons, and the Public Law and Legal Theory Commons

\section{Recommended Citation}

van Aaken, Anne (2009) "Defragmentation of Public International Law Through Interpretation: A Methodological Proposal," Indiana Journal of Global Legal Studies: Vol. 16 : Iss. 2 , Article 5.

Available at: https://www.repository.law.indiana.edu/ijgls/vol16/iss2/5

This Symposium is brought to you for free and open access by the Law School Journals at Digital Repository @ Maurer Law. It has been accepted for inclusion in Indiana Journal of Global Legal Studies by an authorized editor of Digital Repository @ Maurer Law. For more information, please contact rvaughan@indiana.edu.

\section{$\Psi$}

JEROME HALL LAW LIBRARY

INDIANA UNIVERSITY

Maurer School of Law
Bloomington 


\title{
Defragmentation of Public International Law Through Interpretation: A Methodological Proposal
}

\author{
Anne van Aaken*
}

\begin{abstract}
Fragmentation of public international law (PIL) is perceived as a growing problem and answers to it are proliferating. International courts and tribunals are adjudicating ever more on issues that would be considered - were they not transnational or international in nature - constitutional problems. In national law, countervailing values, or intra-constitutional conflicts, are reconciled through a balancing of those values that is usually embedded in the application of the proportionality principle. A similar mechanism in PIL remains underdeveloped from a methodological point of view. This article aims to develop a methodological proposal for defragmentation through interpretation, drawing on legal theory, to be more precise on a theory of balancing.
\end{abstract}

\section{INTRODUCTION}

The current state of public international law (PIL) is the subject of an evergrowing literature that is descriptive, explanatory, or idealistic in nature. The issues debated center around de-formalization, fragmentation, and legal pluralism. ${ }^{1}$ European scholars often try to find answers to those perceived problems through a constitutionalist thinking of the international order, bringing back unity and consistency as it is present in national legal orders. One way is instituting hierarchy, but that only

* Max-Schmidheiny Tenure Track Professor of Law and Economics, Public Law, International and European Law, University of St. Gallen, Switzerland. E-mail: anne.vanaaken@unisg.ch. I would like to thank the organizers and participants of the Kandersteg conference for a fruitful discussion and Stefan Voigt and Rekha Oleschak for helpful comments.

1. See generally Sol Picciotto, Constitutionalizing Multilevel Governance?, 6 INT'L. J. Const. L. 457 (2008).

Indiana Journal of Global Legal Studies Vol. $16 \# 2$ (Summer 2009)

CIndiana University Maurer School of Law - Bloomington 
covers a small part of PIL. Another part, and the focus of this article, is defragmentation through interpretational methods at the international level. Most of the scholarship has been devoted to showing that there is a need for international constitutionalism or to describing that we can already diagnose global constitutionalism, often by taking a positivist or idealist view and mostly focusing on the interaction of international law and national law. I would like to go a step further and start from the assumption that many of the values enshrined in PIL can be viewed as constitutional principles. These principles are largely consented to and positivized in international law. A discourse of justification is, while still needed, not as pressing as it once was. Rather, a discourse of application comes to the fore if the goal of unity and consistency for PIL as a whole is pursued, thus mitigating the dangers arising from different-and possibly conflicting-regimes. International courts and tribunals are proliferating ${ }^{2}$ and adjudicating on issues that would be considered-were they not transnational or international in nature-constitutional problems. In national law, countervailing values, that is intra-constitutional conflicts, are reconciled through a balancing of those values, usually embedded in the application of the proportionality principle. A similar mechanism in PIL remains underdeveloped from a methodological point of view. This article aims to develop a methodological proposal for defragmentation through interpretation, drawing on legal theory.

Different regimes in PIL pursue different goals. World Trade Organization (WTO) law pursues free trade; investment law pursues the protection of foreign investors and development; international human rights law pursues the protection of basic human rights; and multilateral environmental agreements pursue the protection of the environment. But as the International Law Commission's (ILC) Report on the Fragmentation of International Law states, many cases cannot be easily classified into these different regimes. ${ }^{3}$ A dispute before the WTO Appellate Body can easily raise human rights or environmental issues. Similarly, a property dispute before the European Court of Human Rights can entail investment law issues. Conversely, investment disputes can raise human rights and environmental concerns. ${ }^{4}$ Much depends on the forum chosen and the law under which jurisdiction arose. Both investment and trade are areas in international law including regulatory mat-

2. Cesare P.R. Romano, The Proliferation of International Judicial Bodies: The Pieces of the Puz$z l e, 31$ N.Y.U. J. Int'L. L. \& PoL. 709, 729 (1998).

3. Int'l Law Comm'n [ILC], Report of the Study Group of the International Law Commission, Fragmentation of International Law: Difficulties Arising from the Diversification and Expansion of International Law, II 21-26, U.N. Doc. A/CN.4/L.682 (Apr. 13, 2006) (prepared by Martti Koskenniemi).

4. See generally Anne van Aaken, Fragmentation of International Law: The Case of International Investment Law, 17 FinNisH Y.B. INT'L L. $91-130$ (2008). 
ters that would require, were they not transnational, administrative or constitutional adjudication involving other principles like human rights or environmental protection. I will concentrate here on "investment and..." issues for exemplification, but the interpretative steps suggested here are applicable in the wider realm of conflicts.

Although interpretative smoothing of the fragmented international law might be a second-best solution, it is no panacea. It would be more desirable to have international lawmakers who think about fragmentation issues to clarify the relationship between treaties in their codification and through more explicit hierarchies. Since this is rarely found, I propose to use constitutional interpretational methods, specifically the balancing approach, to mitigate the tension between human rights law and other areas of international law. I draw on the Vienna Convention on the Law of Treaties (Vienna Convention), ${ }^{5}$ especially Article 31(3)(c), as well as a theory of balancing developed in German legal theory. As the ILC Report on Fragmentation noted: "contrary to what is sometimes suggested, conflict-resolution and interpretation cannot be distinguished from each other. Whether there is a conflict and what can be done with prima facie conflicts depends on the way the relevant rules are interpreted. This cannot be stressed too much." ${ }^{\circ 6}$ Defragmentation of international law can be achieved through constitutional interpretational means. I also discuss the potential and the limits of this approach.

This article proceeds as follows. In Part 1 , the fragmentation phenomenon in. international law, including pleas for constitutionalization, is briefly described in order to justify the application of constitutional interpretation. Part II discusses the interpretational methods with a focus on Article 31(3)(c) of the Vienna Convention. Its use will be outlined in Part III, drawing on the theory of balancing from constitutional law. Part IV offers possible applications that are meant to illustrate the potential of this interpretational method.

\section{Fragmentation and Constitutionalism}

Although not everyone views the fragmentation of PIL as problematic or solvable, there is broad consensus that every legal order, including the international one, should be as coherent and unified as possible. The ILC has considered institu-

5. Vienna Convention on the Law of Treaties, May 23, 1969, 1155 U.N.T.S. 331 [hereinafter Vienna Convention].

6. ILC, supra note $3,9412$.

7. See generally Andreas Fischer-Lescano \& Gunther Teubner, Regime-Collisions: The Vain Search for Legal Unity in the Fragmentation of Global Law, 25 MicH. J. INT'L L. 999 (2004) (arguing that the fragmentation of PIL mirrors the social fragmentation and rationality behind the different regimes). 
tional as well as substantive fragmentation of PIL a sufficient threat to the international legal order to merit the issuing a report. At the forefront of the discussion is the relationship between WTO Agreements ${ }^{8}$ on the one hand, and other areas of international law, such as multilateral environmental agreements or international human rights law, on the other. ${ }^{9}$ Rather neglected, but of equal importance, are "investment" issues, which have recently gained more attention. ${ }^{10}$ Although international human rights law is often viewed as being at the forefront of constitutionalist claims, ${ }^{11}$ the role of human rights in non-human rights issues on the international level is less developed, certainly from a legal methodology point of view. Thus, I will concentrate on those potential international intra-constitutional conflicts.

Legal conflicts can be defined narrowly, thus limiting the scope of the issues to be examined, or they can be defined more broadly. ${ }^{12}$ Following the ILC Report on Fragmentation, ${ }^{13}$ I adopt a broad notion of what constitutes a conflict, as this allows a more complete analysis of treaty interaction. A conflict exists not only when "a party to two treaties [can] comply with one rule only by thereby failing to comply with another rule," but also when a treaty "frustrate[s] the goals of another treaty without there being any strict incompatibility between their provisions." ${ }^{14}$ I will follow this broader definition here.

8. Marrakesh Agreement, Apr. 15, 1994, 1867 U.N.T.S. 154.

9. See, e.g., Joost Pauwelyn, Conflict of Norms in Public International Law: How WTO Law Relates to Other Rules of International Law (2003); Rüdiger Wolfrum \& Nele Matz, Conflicts in International Environmental Law (2003); Philip Alston, Resisting the Merger and Acquisition of Human Rights by Trade Law: A Reply to Petersmann, 13 Eur. J. INT'L L. 815 (2002); Robert Howse, Human Rights in the WTO: Whose Rights, What Humanity? Comment on Petersmann, 13 Eur. J. Int'L L. 651 (2002). But see Gabrielle Marceau, WTO Dispute Settlement and Human Rights, 13 Eur. J. INr'L L. 753 (2002); Ernst-Ulrich Petersmann, Time for a United Nations "Global Compact" for Integrating Human Rights into the Law of World-wide Organisations: Lessons from European Integration, 13 EuR. J. INT'L L. 621 (2002).

10. See generally Moshe Hirsch, Interactions Between Investment and Non-Investment Obligations in International Investment Law, in Oxford HandBook of International Investment Law 154 (Peter Muchlinski et al. eds., 2008); van Aaken, supra note 4.

11. Stephen Gardbaum, Human Rights and International Constitutionalism, in Ruling The World? Constitutionalism, International Law and Global Government (Jeffrey L. Dunoff \& Joel Trachtman eds., forthcoming 2009), available at http://papers.ssrn.com/sol3/papers.cfm? abstract_id $=1088039$.

12. See Nele Matz, Wege zur Koordinierung völkerrechtlicher Verträge: Völkervertragsrechtliche und institutionelle Ansätze 8-18 (2005); Wolfrum \& Matz, supra note 9, at 6-13; Bruno Simma, Self-Contained Regimes, 16 Netr. Y.B. INT'L L. 111 (1985); C. Wilfred Jenks, The Conflict of Law-Making Treaties, 30 BRIT. Y.B. INT'L L. 401, 418 (1953).

13. ILC, supra note 3.

14. Id. II 24; see also Jenks, supra note 12 , at 426. 
The debates on hierarchy, fragmentation, and deconsensualization in international law alluded to at the beginning, and novel structures, such as administrative networks, are closely connected to the debate on international constitutionalism. This increasingly broad debate cannot be reflected here but will only be alluded to if necessary. I will concentrate on constitutionalism as a means of solving fragmentation problems. Constitutionalism has to be differentiated from the constitution and constitutionalization. ${ }^{15}$

Constitution is traditionally associated with nation-states, even more so among German scholars. This is even reflected in the notions used (Verfassungsstaat, Rechtsstaat, Staatsvolk), which makes it more difficult for German scholars to imagine a constitution without a state and its demos. ${ }^{16}$ This historical understanding of constitution, with its restricting German terminology, is not used here. Instead, a functional approach is taken. Following others, I understand the term constitution in a normative sense as the sum of the basic and materially most important legal norms that comprehensively regulate the social and political life of a polity and usually have special impediments for modification..$^{17}$ The norms do not have to be written down in one single document. ${ }^{18}$ They include the most basic values of a polity, as well as its institutional and procedural organization, and can be reformulated in decision theory terms as principles to be optimized.

Constitutionalization denotes the process by which constitutional law comes into being, the emergence of constitutional law. There is broad consensus that international law has developed immensely since World War II and increasingly

15. See Anne Peters, Compensatory Constitutionalism: The Function and Potential of Fundamental International Norms and Structures, 19 LEIDEN J. INT'L L. 579, 581-84 (2006) (providing a very good overview of the definitions).

16. See Brun-Otto Bryde, International Democratic Constitutionalism, in Towards World Constitutionalism: Issues in the Legal Ordering of the World Community [hereinafter Towards Worlo Constitutionalism] 103, 105 (Ronald St. John MacDonald \& Douglas M. Johnston eds., 2005); Brun-Otto Bryde, Konstitutionalisierung des Völkerrechts und Internationalisierung des Verfassungsrechts, 42 DeR STAAT 61 (2003) (critiquing this idea). Of course, there are substantive reasons behind this "thick" notion of constitution, which is said to need a demos (Staatsvolk). See Dieter Grimm, The Constitution in the Process of Denationalization, 12 Constellations 447 (2005); Josef Isensee, Staat und Verfassung, in Handbuch Des Stantrech ts I at 591 (1987).

17. See Peters, supra note 15, at 581 (not taking into account the changeability); see also PHiLiP Allott, Eunomia: New Order for a New World 167 (1990).

18. For example, the British and the Israeli Constitutions function without a formal, integrated, written constitution. In 1995, the Israeli Supreme Court held that the eleven periodically enacted Basic Laws would function as the nation's constitution, and that the Court would exercise an American-style power of judicial review. See Dalia Domer, Does Israel Have a Constitution? 43 St. Lou Is U. L.J. 1325 (1999); Martin Edelman, The New Israeli Constitution, 36 Middle E. Srud. 1 (2000). 
restricts the sovereignty of states, or their domaine reservé (but how one judges that process is a normative question). Whereas most scholars draw a distinction between the old law of coexistence, the interim law of cooperation, and the current process of constitutionalization, ${ }^{19} \mathrm{Christian}$ Tomuschat uses four steps to describe the evolution: first, international law as a law of coexistence; second, international law as a law of cooperation; third, international law as a comprehensive blueprint for social life; and fourth, international law of the international community. ${ }^{20}$

This process came about due to the de-territorialization of the economic, environmental, and social problems to be solved, and hence contributed to an increasingly problematic disability of the nation-state to continue alone to fulfill its traditional functions, such as regulating social order and protecting its citizens. Increased global interdependence and transnational actors building up transnational networks called for more dense international norms. This was not only due to new real world developments that called for international regulation, but also in order to compensate for deficits of fulfilling the traditional functions of the state ${ }^{21}$ and its subsequent disaggregation due to delegated norm generation by international organizations, transnational cooperation of executive bodies in networks, ${ }^{22}$ as well as more prominent private standard setting. ${ }^{23}$ Further legal phenomena cited as evidence for international constitutionalization include growing nonconsensual norm generation on the international plane, ${ }^{24}$ creation of hierarchies of international law through jus cogens and Article 103 of the U.N. Charter, the emergence of individu-

19. See, e.g., Peters, supra note 15 , at 580; Towards World Constitutionalism, supra note 16 , at 111.

20. Christian Tomuschat, International Law: Ensuring the Survival of Mankind on the Eve of a New Century, General Course on Public International Law, 281 Recueil des Cours: Académie de Drolt International de La Haye 13,56-58 (1999). For an analysis of the General Course of Tomuschat, see also Armin von Bogdandy, Constitutionalism in International Law, 47 HARv. INT'L L.J. 223 (2006).

21. See Peters, supra note 15 (discussing compensatory constitutionalism).

22. See generally Anne-Marie Slaughter, A New World Order (2004). But see Anne van Aaken, Democracy in Times of Transnational Administrative Law: The Case of Financial Markets, in Perspectives and Limits of Democracy 41 (Harald Eberhard et al. eds., 2008) (arguing for transnational cooperation in a standard setting in the financial market sector).

23. See Christian Walter, Constitutionalizing (Inter)national Governance-Possibilities for and Limits to the Development of an International Constitutional Law, 44 German Y.B. INT'L L. 170, 173, 188 (2001); see also Picciotto, supra note 1.

24. See Laurence R. Helfer, Nonconsensual International Lawmaking, 2008 U. ILL. L. Rev. 71 (2008); see also Bardo Fassbender, The Meaning of International Constitutional Law, in TownRds World Constitutionalism, supra note 16, at 843-44; Christian Tomuschat, Obligations Arising for States Without or Against Their Will, 241 Recueil des Cours: Académie de Droit International DE LA HAYE 199 (1993) (discussing the growing nonconsensual character of PIL). 
als as subjects of international law, and the possibility of direct effect. ${ }^{25}$ Nevertheless, some scholars view the possibility of compensation for the loss of constitutional functions on the national plane as too idealistic. "[I]t is inevitable that, for the time being, a bundling of constitutional functions as it has been achieved by the nation state will remain impossible. It has been lost in the level of the nation state and, at the moment, it cannot be achieved elsewhere." ${ }^{26}$ I will try to show that interpretative methods can at least mitigate the problem.

Constitutionalism is defined in various ways that often considerably overlap. The understandings behind the term constitutionalism differ wildly. ${ }^{27}$ This is also due to varying ideas hidden behind the term, although some basic tenets can be filtered out. Joseph Weiler, however, states:

[C]onstitutionalism is, too (some would say only), but a prism through which one can observe a landscape in a certain way, an academic artefact with which one can organize the milestones and landmarks within the landscape (indeed, determine what is a landmark or milestone), an intellectual construct by which one can assign meaning to, or even constitute that which is observed. ${ }^{28}$

In the current discussion, four foci can be distinguished, ${ }^{29}$ all arguing for constitutionalism, and some of them overlapping in their scope. First, some have focused on defining the substratum of constitutionalism, that is, the community for which the constitution is designed. For example, they center on the question of whether it is possible to filter out a notional evolution for an international community without the necessary element of the state. ${ }^{30}$ Second, some have concen-

25. For the latter as a means of constiutionalization, see Armin von Bogdandy, Pluralism, Direct Effect, and the Ultimate Say: On the Relationship Between International and Domestic Constitutional Law, 6 InT'L J. Const. L. 397 (2008).

26. Walter, supra note 23, at 188.

27. See generally Fassbender, supra note 24.

28. J.H.H. Weiler, The Reformation of European Constitutionalism, 35 J. Соммом Mкт. Srud. 97, 99 (1997); see also Peters, supra note 15, at 605 (correctly pointing out that the hermeneutic premise makes reconstruction of (legal) texts not only necessary, but unthinkable, without interpretation).

29. Walter, supra note 23, at 171.

30. See, e.g., Andreas L. Paulus, Die internationale Gemeinschaft im Völkerrecht (2001); Bruno Simma \& Andreas L. Paulus, The "International Community": Facing the Challenge of Globalization, 9 Eur. J. INT'L L. 266 (1998); Tomuschat, supra note 20, at 161; see also Walter, supra note 23, at 172 (citing Draft Articles on Responsibility of States for Internationally Wrongful Acts, art. 42(b), art. 48, U.N. Doc. A/CN.4/L.602/Rev.l (July 26, 2001) (referring only to the "international community," but not to the "international Community of States," as in Vienna Convention, supra note 5, art. 53)). 
trated on the question of whether there are international constitutions as legally binding frameworks for international organizations, ${ }^{31}$ states, or the international community. ${ }^{32}$ There is no consensus, though, whether constitutionalism is to be viewed as a phenomenon applicable to the entire international community, with the U.N. Charter as a constitutional document, ${ }^{33}$ or whether it takes place only in sectoral regimes, such as WTO law or human rights law. ${ }^{34}$ It might well be that international organizations such as the WTO have their own sectoral constitution, but that would not weaken our case for constitutional interpretation.

Third, many authors have a normative vision of a world order embedded in constitutionalism and are "striving for a global legal community that frames and directs political power in light of common values and a common good." 35 Here, the authors focus on substantive issues that show a tendency to restrict national sovereignty in an as yet unknown way. Although no consensus exists as to what the constitutional functions in PIL are, some common ground can be found. A focus on constitutional functions allows us to transpose the term constitutionalism to the European Communities as well as to the international sphere.

Different functions have also been discussed. A more minimalist notion deals only with organizing and institutionalizing a polity; a more specific notion relates to "rules and principles fulfilling typical constitutional functions ... [that] constitute a political entity as a legal entity, to organize it, to limit political power, to offer

31. Often the foundational treaties of international organizations are viewed as partial constitutions, for example, in the WTO Agreement, the World Health Organization, and the U.N. Those functional constitutions thus embody the "legal framework" within which an autonomous community of a functional (sectoral) nature realizes its respective functional goal, such as trade liberalization, human rights protection, or the maintenance of international peace and security. Erika de Wet, The International Constitutional Order, 55 INT'L \& CoMP. L.Q. 51,53 (2006); Walter, supra note 23, at 193.

32. See, e.g., Pierre-Marie Dupuy, The Constitutional Dimension of the Charter of the United Nations Revisited, 1 Max Planck Y.B.U.N.L. 1 (1997); Bardo Fassbender, The United Nations Charter as Constitution of the International Community, 36 Colum. J. TRAnsnat'L L. 529 (1998).

33. See, e.g., Fassbender, supra note 32; Fassbender, supra note 24; Ronald St. John MacDonald, The International Community as a Legal Community, in Towards World Constitutionalism, supra note 16 , at 108.

34. See Walter, supra note 23 , at 195 ("Constitutionalization only occurs within the various sectoral regimes, but fails to reach the international community as a whole. Given the limited areas in which the Security Council may take legally binding decisions, this statement is also true for the United $\mathrm{Na}$ tions."). But see Ernst-Ulrich Petersmann, Constitutionalism, International Law and "We the Peoples of the United Nations", in Tradition und Weltoffenheit des Rechts 291 (Hans-joachim Cremer ed., 2002). For the constitutionalization of WTO, see Ernst-Ulrich Petersmann, Human Rights, Constitutionalism and the World Trade Organization: Challenges for World Trade Organization Jurisprudence and Civil Saciety, 19 Leiden J. INT'L L. 633 (2006).

35. von Bogdandy, supra note 20, at 223 
political and moral guidelines, to justify governance, and, finally, to contribute to integration" (emphasis added) ${ }^{36}$ Here, international constitutional law is defined, following Anne Peters' suggestion, as "the bulk of the most important norms which regulate political activity and relationships in the global polity (consisting of states and other subjects of international law). ${ }^{{ }^{37}}$ Put more abstractly, a constitution is supposed to limit, guide, and legitimize politics. ${ }^{38}$

Others concentrate on developing a substantive substratum of common values and principles. Foremost among these are the basic norms that constitute a common core of values of the international community. As Brun-Otto Bryde has put it, "[a] constitutionalist concept of international law tries to bind these actors [states and international organizations] . . . to substantive constitutional principles, especially the rule of law and human rights." 39

Anne Peters also offers a "thicker" definition. Here, substantive functions are added, such as human rights and the separation of powers, as necessary elements, as well as other functions, such as democracy and a minimum of social security guarantees. ${ }^{40}$ More pertinent to the international sphere, Tomuschat views this "thick" constitutional function with respect to international law as "safeguarding international peace, security and justice in relations between States, and human rights as well as the rule of law domestically inside States for the benefit of human beings, who, in substance, are the ultimate addressees of international law."41 Thus, classical functions of the nation-state, such as safeguarding individual liberty, freedom, and safety, are transferred to the international sphere. The European Court of Human Rights even declared the European Convention on Human Rights to be a "constitutional instrument of European public order ..." .42 "having a peremptory character. ${ }^{2 \times 3}$

36. Peters, supra note 15, at 585; see also Anne Peters, Elemente einer Theorie der Verfassung Europas (2001).

37. Peters, supra note 15 , at 582 (not taking into account the changeability); see also de Wet, supra note 31 , at 53 ("This article extends the use of the term constitution ... to describe a system in which the different national, regional and functional (sectoral) constitutional regimes form the building blocks of the international community ('international polity') that is underpinned by a core value system common to all communities and embedded in a variety of legal structures for its enforcement.").

38. Peters, supra note 15, at 585; von Bogdandy, supra note 20.

39. Bryde, International Democratic Constitutionalism, supra note 16, at 106.

40. Peters, supra note 15 , at 585.

41. Tomuschat, supra note 20, at 23.

42. Loizdou v. Turkey, App. No. 15318/89, 23 Eur. Ct. H.R. 513, I 75 (1997).

43. Bosphorus Hava Yollari Turzm ve Ticaret Anonim Sirketi v. Ireland, App. No. 45036/98, 42 Eur. Ct. H.R. 1, I 154 (2005). 
No matter how one views that debate, for my purpose here, it is enough to accept that first, unity of PIL is desirable, and second, that PIL encompasses constitutional functions embedded in principles. Constitutionalism of the international community can thus focus on substantive values or the common good, which might not be found in one sectoral regime alone, but in the consideration of the different principles found in the different regimes and their reconciliation. In German national constitutional terms, this would be called praktische Konkordanz: reconciling different constitutional principles in a most considerate way. Thus, if we think in constitutional functions, it does not matter for my purpose whether there are only sectoral constitutions or one encompassing constitution; "global constitutionalism does not require global constitutional law."

What, then, are the "constitutional principles" to be considered on the international plane? The "empirical" case to be found for international constitutionalism has to be unearthed in different sectoral developments and filtered out by inductive doctrinal work. The legal phenomena is the empirical material. The areas mentioned in the literature are mainly international human rights, which have a tendency to supersede national constitutional law, international humanitarian law, self-determination, international criminal law, the increasingly extensive legislative practices of the U.N. Security Council acting under Chapter VII of the U.N. Charter, ${ }^{45}$ and some aspects of international environmental law. I wish to also add international trade law and international investment law (principles of individual property rights and freedom of profession or occupation and free trade). I concentrate in this article on substantive legal principles, such as human rights, on the one hand, and investment principles on the other. But the constitutional principles to be considered may well be extended to others, like environmental protection.

It is submitted that in order to strive for unity of the international legal order, constitutional interpretation is an adequate means, if only a second-best solution in the absence of hierarchy and explicit drafting. This is not a new idea, but until now, it has rather been stated as a desideratum in the literature on international constitutionalism. No in-depth legal theoretical or methodological analysis has been undertaken, certainly not for horizontal conflicts of "intra-constitutional" conflicts. It is worth quoting Bryde in full:

44. Gardbaum, supra note 11 , at 30 .

45. MacDonald, supra note 33, at 862 ("Article 103 represents one of the most persuasive arguments in favor of the view that the Charter is in fact a constitution."). 
Methodologically, the point of reference for classical international law has been private contract law. The commanding inspiration for interpretation is the parties' intent. ... With a changed structure of international law in which the interests of mankind is [sic] paramount and in which lawmaking is subjected to constitutional principles, the methodology, too, can be and must be constitutionalized. Interpretation of international law must be directed towards the attainment of the constitutional principles. These constitutional principles are much more open textured and therefore much more adaptable to new circumstances and to a reception of normative arguments, especially the results of a human rights discourse. ${ }^{46}$

Conflicts of values and principles of different areas of PIL can thus be mitigated through the balancing of those competing principles. This helps in solving intra-constitutional conflicts on the international plane.

\section{Defragmentation Through Interpretation}

Constitutionalized legal systems are characterized by rules of conflict, the most important one being the lex superior rule, which gives constitutional law precedent over other laws. Unless one claims that, for example, human rights should always "trump" other international law-a claim difficult to substantiate-we are still left with an overwhelmingly horizontally structured system, with the exception of jus cogens (which does contain some human rights) and Article 103 of the U.N. Charter. ${ }^{47}$

Clearly, there are several functions of human rights in the context of international constitutionalism. They fill gaps in the national protection of human rights, either substantially or with a view to territorial limits of the national constitution.

46. Bryde, International Democratic Constitutionalism, supra note 16, at 109.

47. For details, see J.H.H. Weiler \& Andreas L. Paulus, The Structure of Change in International Law or Is There a Hierarchy of Norms in International Law?, 8 EUr. J. INT'L L. 545, 558-65 (1997). This finding may be impacted by Kadi/Barakaat Joined Cases C-402/05 and C-415/05 Eur. Ct. J., 1303 (2008) ("Those provisions cannot, however, be understood to authorize any derogation from the principles of liberty, democracy and respect for human rights and fundamental freedoms enshrined in Article 6(1) EU as a foundation of the Union."); Id. I 307 ("Charter of the United Nations would have primacy over acts of secondary Community law but that primacy at the level of Community law would not, however, extend to primary law, in particular to the general principles of which fundamental rights form part."); Id. II 35, 45 (stating G.A. Maduro's forceful pleading for upholding the rule of law and human rights in times of terrorism). 
They impose limits on how a state may treat its own population and add a new commitment by "outsourcing" the review of human rights—a "second set of legal limits." ${ }^{\prime 48}$ The same holds true for environmental protection as a public good. All of these functions clearly have a vertical implication: they describe the relationship between the international and the national legal orders. ${ }^{49}$ But there is another function of the international human rights system and environmental principles, the horizontal function. It gives guidelines to international courts in interpreting non-human rights or non-environmental law. This is the point on which I will subsequently focus - that is, not the vertical function of one area in international law, but its horizontal function in international adjudication.

There are many ways for international courts and tribunals to take into account other PIL when adjudicating on the basis of one special treaty. Choosing interpretation under Article 31(1) or interpretation under Article 31(3)(c) of the Vienna Convention can be a difficult task. Nevertheless, any starting point for the interpretation of treaties is Articles 31 and 32 of the Vienna Convention. ${ }^{50}$ Article 31 (1) states the general considerations in interpretation: (1) the ordinary meaning of the terms of the treaty, (2) the context, and (3) the treaty's object and purpose. It is widely accepted that the aim of treaty interpretation is to give effect to the intention of the parties. There is no consensus on whether there is a hierarchy in the arguments. It is often held, although disputed, that common law lawyers tend to stress the ordinary meaning, ${ }^{51}$ whereas civil law lawyers tend to stress the object and purpose as a teleological method. ${ }^{52}$ Reconsidering the debate on interpretative methods of Article 31(1) is beyond the scope of this article.

48. Gardbaum, supra note 11 , at 29.

49. See generally The Role of Domestic Courts in Treaty En forcement (David Sloss \& Derek Jinks eds., 2009).

50. See e.g., Richard K. Gardiner, Treaty Interpretation (2008); 1 Oppenheim's International Law, pts. 2-4, 1266-75 (Sir Jennings \& Arthur Watts eds., 1995). Those rules of interpretation are accepted as customary international law. Supplementary means of interpretation such as contra preferentem, in dubio mitius, or expressio unius est exclusio alterus are discussed as well. Id. at 1275-82.

51. It is well known from legal theory that in order to construct the ordinary meaning of a term, exactly those other interpretational methods are needed. "The finding whether a treaty is clear or not is not the starting point but the result of the process of interpretation." OPPENHEIM's INTERnationaL Law, supra note 50, at 1267.

52. For different schools of thought in treaty interpretation, see Gerald Fitzmaurice, Law and Procedure of the International Court of Justice 1951-4: Treaty Interpretation and Other Treaty Points, 33 BRIT. Y.B. IN T'L L. 203 (1957); Thomas Wälde, Interpreting Investment Treaties: Considerations and Examples Highlighting Confusion Arising and Clarity Desired, in Festschrift Christoph Schreuer (forthcoming 2009). But see Douglas M. Johnston, World Constitutionalism in the Theory of International Law, in 
There are different openings for including other special international laws into the regime at hand, and each gives different interpretational leeway to international courts and tribunals. Thus, they can only be discussed with regard to the treaty being interpreted. But the different means are nevertheless stated here in the abstract. First, the treaty at hand may explicitly refer to other PIL, clarifying the relationship between different treaties and calling for the application of other treaties as, for example, in Article 104 of the North American Free Trade Agreement and clarifying precedence. ${ }^{53}$ Second, a treaty norms may be unclear and another PIL norm may be used to clarify the meaning with the interpretational means of Article 31(1) of the Vienna Convention. Thus, the terms of the treaty in their ordinary meaning can be informed by the usage of the same term in other treaties. In this case, balancing is not the issue, but rather clarifies the content through definitions. Third, the terms of the treaty at hand can be interpreted in the light of the object and purpose of the treaty, which may open gates to other norms of PIL.

The object and the purpose of a treaty can be of special interest for defragmenting interpretation. If the object and the purpose ${ }^{54}$ of the treaty also contain human rights or sustainable development goals, these may be used in a teleological interpretation of the treaty itself, leading to harmonious interpretation. If, for example, a bilateral investment treaty (BIT) contains a reference to human rights in its preamble, the interpretation of the treaty should take human rights concerns into account, even if human rights protection is not the main purpose of the treaty. ${ }^{55}$

Most "other PIL" treaties do not contain such a reference. In WTO law, the

Towards World Constitutionalism, supra note 16, at 3 (calling European lawyers more positivistic and Anglo-Saxon lawyers more realist, the latter allowing for more teleological thinking).

53. "Relation to Environmental and Conservation Agreements: 1 . In the event of any inconsistency between this Agreement and the specific trade obligations set out in: a) the Convention on International Trade in Endangered Species...; b) the Montreal Protocol on Substances that Deplete the Ozone Layer. . ; c) the Basel Convention on the Control of Transboundary Movements of Hazardous Wastes and Their Disposal ... such obligations shall prevail to the extent of the inconsistency, provided that where a Party has a choice among equally effective and reasonably available means of complying with such obligations, the Party chooses the alternative that is the least inconsistent with the other provisions of this Agreement." North American Free Trade Agreement, art. 104, U.S.Can.-Mex., Dec. 17, 1992, 32 I.L.M. 289, 297 (1993) [hereinafter NAFTA].

54. The object and purpose become especially more important in treaties with a constitutional character, such as the Treaty of the European Communities. Generally, the purpose of a treaty can be found in its preamble and annexes. See Fitzmaurice, supra note 52, at 227-29 (referring to court decisions).

55. See, for example, the Draft Model Norwegian Bilateral Investment Treaty (2007), stating in its preamble, "Reaffirming their commitment to democracy, the rule of law, human rights and fundamental freedoms in accordance with their obligations under international law, including the principles set out in the United Nations Charter and the Universal Declaration of Human Rights." 
general exceptions in Article XX of the General Agreement on Tariffs and Trade (GATT) ${ }^{56}$ or Article XIV and Article XIV bis of the General Agreement on Trade in Services (GATS) are relevant opening provisions. The Appellate Body of the WTO has accepted, when interpreting Article XX of GATT, that the preamble may give guidance on how to interpret the term "exhaustible natural resources" of Article XX $(\mathrm{g}) .^{57}$

Fourth, if the procedural law or the substantive law under which courts or tribunals decide refers to "international law as applicable," but does not specify which PIL is applicable, tribunals may use other PIL when adjudicating on the basis of that treaty. ${ }^{58}$ This is not the case in WTO law, where Article 3.2 of the Dispute Settlement Understanding (DSU), in conjunction with Article 19.2, restricts the panels as well as the Appellate Body to a greater extent. But in investment law, Article 42(1) of the Convention on the Settlement of Investment Disputes Between States and Nationals of Other States refers to "international law as applicable," and most BITs do the same. This, though, does not answer the question of which PIL is applicable, and tribunals have not done much to clarify the issue either. This problem must be left open here. It suffices to say that the point between the application of other law and the interpretation in the light of other law is a fine line.

Last, but not least, tribunals may interpret treaty norms by using other PIL applicable between the parties as foreseen in Article 31(3)(c) of the Vienna Convention. Its explicit use has only recently become more frequent, as it has just awoken to its potential significance and literature on its becoming operational is scarce. ${ }^{59}$ The possibility of using Article 31(3)(c) has been discussed for the WTO, but not for investment law, although International Centre for Settlement of Investment Disputes tribunals ${ }^{60}$ have heavily relied on application of the Vienna Convention, ${ }^{61}$ especially

56. As, for example, the Appellate Body has in GATT Article XX in United States-Import Prohibition of Certain Shrimp and Shrimp Products, WT/DS58/AB/R, II 127-31 (Nov. 6, 1998).

57. "While Article XX was not modified in the Uruguay Round, the preamble attached to the WTO Agreement shows that the signatories to that Agreement were, in 1994, fully aware of the importance and legitimacy of environmental protection as a goal of national and international policy. The preamble of the WTO Agreement - which informs not only the GATT 1994, but also the other covered agreements—explicitly acknowledges 'the objective of sustainable development."' Id. II 129.

58. For an extensive discussion on the question of which law is applicable in investment protection adjudication, see generally van Aaken, supra note 4.

59. ILC, supra note 3, I 433.

60. Convention on the Settlement of Investment Disputes Between States and the Nationals of Other States, Mar. 18, 1965, 575 U.N.T.S. 159 [hereinafter ICSID]. Most investment disputes are conducted under this convention.

61. For the application of the Vienna Convention by investment tribunals, see Hirsch, supra note 10; Christoph Schreuer, Diversity and Harmonization of Treaty Interpretation in Investment Arbitration, 
Article 31(1). But they do not resort explicitly to Article 31(3)(c) for interpreting clauses of BITs, even if they use other special PIL for interpretation. But the correct-and more transparent-means of integrating non-investment or non-trade law in investment and trade disputes is the applicability of Article 31(3)(c), under which an interpretation should take into account "any relevant rules of international law applicable in the relations between the parties."

Commentators have viewed Article 31(3)(c) of the Vienna Convention as a "general principle of treaty interpretation, namely that of systemic integration within the international legal system," having the "status of a constitutional norm within the international legal system. In this role, it serves a function analogous to that of a master-key in a large building." ${ }^{13}$ No international law norm can be considered in isolation and it must be interpreted in light of other international law, be it general international law, customary international law, or even other treaty norms.

Richard Gardiner views the different functions of Article 31(3)(c) of the Vienna Convention as following: "(a) resolving time issues (including application of the intertemporal law); (b) completing the legal picture, or filling gaps, in a treaty by reference to general international law; (c) deriving guidance from parallel treaty provisions; (d) resolving conflicting obligations arising under different treaties; (e) taking account of international law developments. ${ }^{64}$ The latter two are of special relevance to this article.

Several issues are discussed in conjunction with the interpretation of Article $31(3)(c)$ of the Vienna Convention. First, which sources of international law may be used-customary norms, general principles, or treaty law? Here, a consensus is emerging, also due to the traveaux préparatoire of the Vienna Convention, ${ }^{65}$ that all sources of international law, including treaties, are meant to be included.$^{66}$ All

3 Transnat'l Disp. Mgmt. (2006), available at http://www.transnational-dispute-management.com/ welcome.html. For examples of NAFTA applications of the Vienna Convention, see Pope \& Talbot v. Canada, III 65-66 (Interim Award of June 26, 2000), available at http://www.international.gc.ca/ trade-agreements-accords-commerciaux/disp-diff/phases.aspx?lang=en; Mondev Int'l v. United States, ICSID (W. Bank) Case No. ARB(AF)/99/2, Second Submission of Canada, II 43, 68 (July 6, 2001), available at http://www.state.gov/documents/organization/18271.pdf.

62. This is the commonly held view. See Marceau, supra note 9, at 780; Joost Pauwelyn, The Role of Public International Law in the WTO: How Far Can We Go?, 95 AM. J. INT'L L. 554, 554-66 (2001).

63. Campbell MacLachlan, The Principle of Systematic Integration and Article 31(3)(c) of the Vienna Convention, 54 INT'L \& Comp. L.Q. 279, 280-81 (2005) (emphasis removed); ILC, supra note 3, I 413.

64. Gardiner, supra note 50, at 260.

65. ILC, supra note 3, at If 429; GARDINER, supra note 50, at 256.

66. ILC, supra note 3, I 21; GARDINER, supra note 50, at 261; Marceau, supra note 9, at 780. 
human rights or environmental law that has acquired the status of customary international law can thus be considered in the application of treaties under Article $31(3)(c)$ without checking if the state parties to the disputes are also state parties to the other treaty applicable to interpretation. ${ }^{67}$

Second, concerning treaties, it remains an open question, in cases of multilateral treaties, whether all parties to the treaty also have to be party to the other treaties relied upon (the identical membership requirement) or whether Article 31(3)(c) already allows for the application of PIL relevant only to the parties in the dispute at hand, greatly enhancing its significance. ${ }^{68}$ Generally, the literature takes the latter, broader view. One, in my view, convincing argument ad absurdum against the identical membership argument was made by Gabrielle Marceau. If a multilateral treaty is to be applied, the greater its membership, the less other treaty law could be taken into account. If, for example, 153 WTO members are party to a human rights treaty, allowing courts to take the human rights treaty into account, then a new acceding member to the WTO that is not party to the human rights treaty would then, under this understanding, prohibit the reference to this human rights treaty later on. In other words, the more successful a multilateral treaty, the more it would have to be read in isolation. ${ }^{69}$

Nevertheless, in the Biotech case, the WTO panel took this narrow view. Here, the European Community argued that its ban on the importation of genetically modified organisms could be justified by non-WTO rules. In particular, it argued that the 1992 Convention on Biological Diversity and the related Biosafety Protocol of 2000 should be taken into account. The panel held that all the parties to the treaty to be interpreted needed to have become parties to that other treaty:

[W]e note that Article 31(3)(c) does not refer to "one or more parties." Nor does it refer to "the parties to a dispute." We further note that Article $2.1(\mathrm{~g})$ of the Vienna Convention defines the meaning of the term "party" for the purposes of the Vienna Convention. Thus, "party" means "a State which has consented to be bound by

67. See, for example, in Korea-Measures Affecting Government Procurement, If 7.96, WT/ DS163/R (May 1, 2000), available at http://www.worldtradelaw.net/reports/wtopanelsfull/korea -govprocurement(panel)(full).pdf. The panel stated that "customary international law applies generally to the economic relations between WTO Members. Such international law applies to the extent that the WTO treaty agreements do not 'contract out' from it."

68. See Gardiner, supra note 50, at 269-75; MacLachlan, supra note 63, at 314-15; Marceau, supra note 9 , at 781 .

69. Marceau, supra note 9 , at 781 . 
the treaty and for which the treaty is in force." It may be inferred from these elements that the rules of international law applicable in the relations between "the parties" are the rules of international law applicable in the relations between the States which have consented to be bound by the treaty which is being interpreted, and for which that treaty is in force. This understanding of the term "the parties" leads logically to the view that the rules of international law to be taken into account in interpreting the WTO agreements at issue in this dispute are those which are applicable in the relations between the WTO Members. ${ }^{70}$

Since the United States is not a member of the Biosafety Protocol, it was not applicable. This argument would confine WTO law back to a "clinical isolation""1 to which it was not meant to be confined. But since it will be almost impossible to find a treaty to which all WTO members are states parties, that is the unfortunate conclusion. The panel also held that the precautionary principle has not acquired the status of customary law, nor has it become a general principle of PIL, and was thus not applicable. ${ }^{72}$

Third, there is the problem that the relevant rules to be taken into account may operate on different levels of generality; they can thus be rules or principles in legal theoretical terms. Rules are undisputedly relevant. But are principles relevant? Although for the purpose of this article, principles are defined in legal theoretical terms, this is not the same notion as the one used in Article 38 of the Statute of the International Court of Justice, which includes "general principles of law recognized by civilized nations" as a source. ${ }^{73}$ It is submitted that the theoretical character of the principles of Article 38 is similar to the principles as understood in legal theoretical terms. As the Biotech Panel held, principles are relevant. Also in the case of the Iron Rhine, ${ }^{74}$ the Tribunal held that:

70. Report of the Panel, European Communities-Measures Affecting the Approval and Marketing of Biotech Products, II 7.68, WT/DS291-3/R, at 333 (Sept. 29, 2006), available at http://www.wto.org/ english/tratop_e/dispu_e/cases_e/ds293_e.htm [hereinafter Biotech].

71. United States-Standards for Reformulated and Conventional Gasoline, WT/DS2/AB/R, at 17 (Apr. 29, 1996), available at http://www.wto.org/english/tratop_e/dispu_e/cases_e/ds2_e.htm.

72. Biotech, supra note 70, I 7.89 .

73. Statute of the International Court of Justice, June 26, 1945, art. 38, 59 Stat. 1031, available at http://www.icj-cij.org/documents/index.php? pl =4\&p2 =2\&p3 $=0$.

74. The Iron Rhine (IJzeren Rijn) Arbitration (Belgium/Netherlands) (2007). 
[T] here is considerable debate as to what, within the field of environmental law, constitutes "rules" or "principles"; what is "soft law"; and which environmental treaty law or principles have contributed to the development of customary international law. Without entering further into those controversies, the Tribunal notes that in all of these categories "environment" is broadly referred to as including air, water, land, flora and fauna, natural ecosystems and sites, human health and safety, and climate. The emerging principles, whatever their current status, make reference to conservation, management, notions of prevention and of sustainable development, and protection for future generations. ${ }^{75}$

The European Court of Human Rights refers also to principles as being relevant under Article 31(3)(c) of the Vienna Convention:

Article 31 para. 3(c) of the Vienna Convention indicates that account is to be taken, together with the context, of "any relevant rules of international law applicable in the relations between the parties." Among those rules are general principles of law and especially "general principles of law recognized by civilized nations" (Article 38 para. 1(c) of the Statute of the International Court of Justice) .... The principle whereby a civil claim must be capable of being submitted to a judge ranks as one of the universally "recognised" fundamental principles of law; the same is true of the principle of international law which forbids the denial of justice. Article 6 para. 1 must be read in the light of these principles. ${ }^{76}$

Those general principles would also fulfill the definition of principles as understood by legal theory: they can be fulfilled more or less and are to be optimized. Although a distinction has to be drawn conceptually between the direct application of other general or special norms of international law in, for example, non-human rights disputes, and the indirect interpretation of non-human rights law by considering human rights law, there might nevertheless be a fine line between applying human rights law directly or importing it through interpretation:

75. Id. I 58 .

76. Golder v. United Kingdom, 1 Eur. Ct. H.R. 524, I 35 (1975). 
In practice ... there is a good chance that the two (application and interpretation) might lapse into each other-such would seem well-nigh inevitable, if only because it would be difficult to apply something without at the same time interpreting it, and to interpret a term without a context in which to apply it. ${ }^{77}$

Article $31(3)(c)$ of the Vienna Convention does not state how potentially conflicting norms have to be integrated systemically, just that they have to integrated. It is worth quoting the ILC Report in full:

None of this predetermines what it means to "confront" a norm with another or how they might enter into "concurrence." These matters must be left to the interpreter to decide in view of the situation. The point is only - but it is a key point-that the normative environment cannot be ignored and that when interpreting the treaties, the principle of integration should be borne in mind. This points to the need to carry out the interpretation so as to see the rules in view of some comprehensible and coherent objective, to prioritize concerns that are more important at the cost of less important objectives. This is all that article $31(3)(\mathrm{c})$ requires; the integration into the process of legal reasoning—including reasoning by courts and tribunals—of a sense of coherence and meaningfulness. Success of failure here is measured by how the legal world will view the outcome. ${ }^{78}$

It is submitted that Article 31(3)(c) allows for what German constitutional lawyers call praktische Konkordanz: $:^{79}$ reconciling different and competing principles of a constitutional order in cases when Article 31(3)(c) allows for the taking into account of other rules and principles of PIL. ${ }^{80}$ Tribunals may thus deal with the intra-consti-

77. Jan Klabbers, Reluctant Grundnormen: Articles 31 (3) (c) and 42 of the Vienna Convention on the Law of Treaties and the Fragmentation of International Law, in Time, History And INTERNAtional Law 141, 144 (Matthew Craven et al. eds., 2007).

78. ILC, supra note 3, I 419.

79. Konrad Hesse, Grundzüge der Verfassungsrechts der Bundesrepublik Deutschland II 72 (1995) ("Verfassungsrechtlich geschützte Rechtsgüter müssen in der Problemlösung einander so zugeordnet werden, daß jedes von ihnen Wirklichkeit gewinnt.... beiden Gütern müssen Grenzen gesetzt werden, damit beide zu optimaler Wirksamkeit gelangen können."). This was followed by the German Constitutional Court and the Court Constitutionel in France.

80. See Gardiner, supra note 50, at 288. 
tutional conflicts of PIL through interpretational means, such as balancing and the principle of proportionality, by using human rights law in the interpretation of nonhuman rights law through Article 31(3)(c). The question of how other rules of PIL are to be incorporated by interpretation is not dealt with by Article 31(3)(c). Like Robert Alexy, I would therefore suggest using a functional approach similar to national constitutional law, based on a theory of rational balancing. ${ }^{81}$

\section{A Theory of Rational Balancing}

The method of balancing is mostly used in constitutional law and finds its most prominent form in the principle of proportionality. Coming from German law, it diffused around most legal systems of the world and deeply into international law. ${ }^{82}$ As the Israeli Supreme Court has held, "[p]roportionality is recognized today as a general principle of international law" ${ }^{13}$ and can thus also be viewed as a meta-principle in PIL. Although it may be named differently and application vary in some details, it is widely applied in all countries with constitutional review, as well as in international law (including, for example, the European Court of Human Rights, as well as by the Appellate Body of the WTO) ${ }^{84}$

The legal theoretical elaboration of the principle of proportionality has been delivered by Robert Alexy. Alexy's work has been cited as "one of the most penetrating, analytically refined, and influential general accounts of constitutional rights available" 85 and "arguably the most important and influential work of constitutional theory written in the last fifty years." ${ }^{~} 6$

81. Robert Alexy, On Balancing and Subsumption: A Structural Comparison, 16 Ratio Juris 433 (2003); Anne van Aaken, A Functional Approach to International Constitutionalism: Methodological Suggestions (Univ. of St. Gallen Law Sch. Law \& Econ. Research Paper Series, Working Paper No. 2008-080), available at http://ssrn.com/abstract $=1137525$.

82. For an extensive description of the diffusion, see Alec Stone Sweet \& Jud Mathews, Proportionality Balancing and Global Constitutionalism, 47 Colum. J. Transnat'L L. 73 (2008).

83. HCJ 2056/04 Beit Sourik Village Council v. The Government of Israel [2004] II 37, http:// www.unhcr.org/refworld/docid/4374ac594.html. This is widely confirmed. See Rosalyn Higgins, Problems and Process: International Law and How We Use It 219 (1994); Theodor Meron, Human Rights and Humanitarian Norms as Customary Law 65 (1989); Jost Delbrück, Proportionality, 3 Encyclopedia Pub. Int'L L. 1140 (Rudolf Bernhardt ed., 1997).

84. For the necessity test in W'TO law, see Panagiotis A. Delimatsis, Determining the Necessity of Domestic Regulations in Services: The Best is Yet to Come, 19 Eur. J. INT'L L. 365, 370-76 (2008).

85. Mattias Kumm, Constitutional Rights as Principles: On the Structure and Domain of Constitutional Justice, 2 INT'L J. Const. L. 574, 596 (2004).

86. Stone Sweet \& Mathews, supra note 82, at 77 (referring to Robert Alexy, Theorie der Grundrechte (1996)). For an English translation, see Robert Alexy, A Theory of Constitu- 
Two main propositions are central to Alexy's theory. First, the distinction between rules and principles, and second, that principles are optimization programs, that is, they have to be realized to the greatest extent possible, given factual and legal constraints. Rules may or may not be applicable, but principles are more or less fulfilled and command optimization given the factual and legal possibilities, thus giving more space to social science considerations. ${ }^{87}$

Conventionally, legal methodology distinguishes between subsumption on the one hand, and balancing or weighing on the other hand. Whereas the first is used in dealing with rules, the latter is used in dealing with principles. Rights, as well as collective goods or goals formulated in the constitution (Staatszielbestimmungen), such as environmental protection, are seen as principles. ${ }^{88}$ Proportionality is thus not confined to individual rights balancing. This should be kept in mind, since the original, and still most common, application of the principle of proportionality is in human rights adjudication, in the national as well as the international spheres, where a legitimate state or public interest might be used to limit human rights, or where the human rights of one person are balanced against those of another. But the principle of proportionality may also be used if two competing public purposes or state interests are at stake, such as free trade and the environment.

Principles are thus applicable even if they are not "fully" satisfied. They are norms that can be more or less realized, such as the democratic principle, the right to freedom of opinion, or the principle of free trade. One may also call them concepts that need to be formalized in the discourse of legal application to find (common) conceptions.$^{89}$ Concepts such as justice, fairness, human rights, peace, and security are concretized in PIL, be it through treaties, custom, or general principles, but they have to be further concretized in the discourse of law application to find (common) conceptions, as they sometimes compete with each other. One realization of this imperative is the proportionality principle.

I will argue here, in accord with Alexy, that balancing is a rational procedure

TIONAL Rights (Julian Rivers trans., 2002). Here, the German version will be used.

87. For the difference between rules and principle as applied here, see Alexy, supra note 86, at 72.

88. Id. at 98; Robert Alexy, Zum Begriff des Rechtsprinzips, in Recht, Vernunft, Diskurs: Studien zur Rechtsphilosophie 177 (Robert Alexy ed., 1995) (also discussing Ronald Dworkin's way of understanding this distinction); see also Ronald Dworkin, Taking Rights Seriously 82, 90 (1978) (confining the notion of principle to rights and names of public goods as policies).

89. Walter B. Gallie, Essentially Contested Concepts, 56 Proceedings of the Aristotelian Soc'y 167 (1956); Wesley N. Hohfeld, Some Fundamental Legal Conceptions as Applied in Judicial Reasoning, in Fundamental Legal Conceptions as Applied in Judicial Reasoning and Other Essays 23 (W.W. Cook ed., 1923). 
in its main part and very close to the reasoning of optimization (or cost-benefit analysis, Pareto optimality). ${ }^{90}$ Formulated in normative decision theory terms, this means the optimality of measures generally, and regulations, laws, and legal acts specifically, is determined by a defined system of goals (the international constitutional principles) and under legal constraints. A "constitution" is viewed as a multicriterial or multidimensional decision system.

Thus, different alternatives can be compared with regard to their contribution to the constitutional objectives. The optimal decision is the alternative that maximizes the net surplus, defined as benefits minus the cost of a measure. Benefits and costs are defined in constitutional terms and include the positive effects of the measure in question on all relevant constitutional principles as benefits and the negative effects as costs. In order to evaluate different alternatives, the proportionality principle of balancing is used.

The proportionality principle is comprised of three sub-principles: the principle of suitability, the principle of necessity, and the principle of proportionality in a narrow sense. The first two sub-principles lend themselves easily to consequentialist and instrumental reasoning; they require comparative institutional analysis regarding the impact on the constitutional principle in question. Here, principles have to be optimized and given factual constraints. The principle of suitability covers the question of whether the measure or the law is, in principle, suitable to achieve its goal. The principle of necessity covers the question of whether there are other, less intrusive means with regard to the constitutional principle in question that are equally able to achieve the stated goal of the measure. Applying the principle of proportionality, as it has been done by the investment tribunals, human rights courts, and the Appellate Body, necessarily includes consequentionalist reasoning. This method of reasoning in turn requires social science analysis if one does not want to resort to the everyday intuitions of judges. If available for the case at hand, it should be used.

The third principle, proportionality stricu sensu, is more open to value judgements and does not lend itself easily to social science approaches, but rather to rational justification in legal application. Here, the principles have to be optimized given legal constraints. Alexy develops a complicated formula, developing scales on the intensity of interference with rights (light, moderate, or serious) and the importance of the right (for example, the right to life has more abstract weight

90. For an extensive discussion of this issue and reformulation of the principle of proportionality, see Anne van Aaken, Rational Choice in der Rechtswissenschaft. Zum Stellenwert der ÖKONOMISCHEN THEORIE IM Recht 288 (2003). 
than freedom of expression, though the concrete weight has to be elaborated on a case-by-case basis). These scales are not arbitrary but are to be justified by giving reasons in order to be contestable. ${ }^{91}$

It is unnecessary to introduce higher criteria for decision-making, but it is necessary to use decision rules and to make them transparent. The mode of reasoning is a discursive one; it is neither decisionism of a judge nor social science application. Normative decision theory has developed many of these rules on the desired level of satisfaction (Theorie des erwünschten Niveaus; in legal speak, the essential content of a principle that may not be violated; Wesensgehalt). A decision rule like that provides for the setting of a required level of satisfaction..$^{92}$ The decision of the German Federal Constitutional Court on the Air-Transport Security Act, for example, set the required level of satisfaction for human dignity so high that any balancing is excluded, following the traditional doctrine in German constitutional law. ${ }^{93}$

But how does the principle of proportionality and Article 31(3)(c) of the Vienna Convention connect? As the ILC Report has stated:

First is the effort to harmonize the apparently conflicting norms by interpreting them so as to render them compatible. Second is the technique whereby the question of validity has been replaced by a question of priority. The norm that will be set aside will remain as it were "in the background," continuing to influence the interpretation and application of the norm to which priority has been given. It follows that, contrary to what is sometimes suggested, conflictresolution and interpretation cannot be distinguished from each other. Whether there is a conflict and what can be done with prima facie conflicts depends on the way the relevant rules are interpreted. This cannot be stressed too much. ${ }^{94}$

91. Alexy, supra note 81 , at 439 .

92. Graphically, one may clarify that by drawing a utility curve in a coordinate plane which allows weighing strictu sensu only in a range above a certain ordinal number. See also ALEXY, supra note 86, at 147. In substance, that is similar to the proposal by Eyal Zamir \& Barak Medina, Law, Morality, and Economics: Integrating Moral Constraints with Economic Analysis of Law, 96 CAL. L. Rev. 323(2008).

93. Bundesverfassungsgericht [BVerfG] [Federal Constitutional Court] Feb. 15, 2006, 1 BvR 357/05; see also Oliver Lepsius, Human Dignity and the Downing of Aircraft: The German Federal Constitutional Court Strikes Down a Prominent Anti-terrorism Provision in the New Air-Transport Security Act, 7 German L.J. 761 (2006), http://www.germanlawjournal.org/pdf/Vol07No09/ PDF_Vol_07_No_09_761-776_Developments_Lepsius.pdf.

94. ILC, supra note 3, III 411-12. 
For intra-constitutional conflicts in PIL, this means that the judge has to first consider whether human rights law informs the interpretation of the non-human rights treaty under Article 31(1) of the Vienna Convention. Second, the judge has to consider whether human rights law is applicable between the parties under Article $31(3)(c)$. This can be the case if the human rights norm in question has acquired the status of customary international law or if both states to the dispute are parties to the human rights treaty in question. The judge then has to balance the principle of the treaty to be interpreted, which is presumably in conflict with the human rights principle in question. In order to illuminate this technique, I give some examples from investment law and trade law below.

\section{Some Possible Applications}

Investment law and trade law both contain potential conflicts with other areas of PIL. As mentioned before, those conflicts would be, were they not transnational, considered intra-constitutional conflicts. In the following Part, I will give some examples of these conflicts. It should be stressed that, whereas in trade law, some kind of balancing has been used and there is more extensive case law, especially through the necessity test in GATT Article XX, ${ }^{95}$ this method has been applied only rarely in investment law. I will thus focus on the latter. ${ }^{96}$ Investment law is being increasingly criticized, mainly because other areas of special international law are viewed as not being sufficiently taken into account. BITs are public international law treaties, giving foreign investors substantive protection against political risks and, therefore, certain actions of their host states. How can tribunals find harmonious interpretation between investment law and non-investment law?

States may explicitly take general human rights-inspired measures in order to fulfill their international or constitutional human rights obligations. Here, arbitral tribunals have considerable scope to interpret the BIT provisions in a way to balance human rights and investor protection, especially if the state has taken a

95. For an excellent overview of the necessity test as used by the panels and the Appellate Body so far and how it could be used under GATS Art. VI (4) - an issue not yet well-developed but crucial in the context of the International Covenant on Economic, Social and Cultural Rights-especially with a view on the privatization of public services, see Delimatsis, supra note 84; Anne van Aaken, Einwirkungen des Völkerrechts auf das Sozialverfassungsrecht am Beispiel der Daseinsvorsorge, in STrukturfragen des Sozialverfassungsrechts 47 (Andreas von Arnauld \& Andreas Musil eds., 2009).

96. For overviews on investment law, see Rudolf Dolzer \& Christoph Schreuer, Principles of International Investment Law (2008); The Oxford Handbook of International InvestMENT Law (Peter Muchlinski et al. eds., 2008). 
nondiscriminatory measure. The most prominent and used protective provisions are indirect expropriation and "fair and equitable treatment." They require investment tribunals to identify the proper reference points for assessing the fairness and equity of measures adopted or maintained by host states.

Those norms, as very indeterminate legal terms, also constitute opening windows for the consideration of human rights norms under Article 31(3)(c) of the Vienna Convention. In the case of indirect expropriation, tribunals may not apply the "sole effects" doctrine but may also include the purpose of the regulatory measure. Thereby, they may include potential environmental obligations or human rights obligations of a state as a reasonable purpose for the national measure in question.

The first tribunal to use the proportionality test in indirect expropriation was, to my knowledge, the Tecmed v. Mexico tribunal. ${ }^{97}$ It deferred to the European Court of Human Rights. The 2004 U.S. Model BIT requires exactly this when it states in its Annex B on expropriation that: "[e]xcept in rare circumstances, nondiscriminatory regulatory actions by a Party that are designed and applied to protect legitimate public welfare objectives, such as public health, safety, and the environment, do not constitute indirect expropriations." This would also be in line with the jurisprudence of the European Court of Human Rights. ${ }^{98}$

The defendant state may then not only invoke its own law, but also international non-investment law, either indirectly through the national law, or directly as a legitimate purpose against which the infringement of investors' rights must be balanced. Furthermore, in the context of fair and equitable treatment, the reference points for judging the fairness and equitableness of a measure could include special areas of PIL. If, for example, a country chooses to introduce protective measures for indigenous tribes and restricts investment, the application of the International Labour Organization Conventions on Indigenous People could enter the interpretation of fair and equitable treatment. ${ }^{99}$ Thus a balancing of conflict-

97. Tecnicas Medioambientales TECMED S.A. v. United Mexican States, ICSID (W.Bank) Case No. ARB (AF) $/ 00 / 2$, I 122 (2003) ("[T] he Arbitral Tribunal will consider, in order to determine if they are to be characterized as expropriatory, whether such actions or measures are proportional to the public interest presumably protected thereby and to the protection legally granted to investments, taking into account that the significance of such impact has a key role upon deciding the proportionality.").

98. See, e.g., James and Others v. United Kingdom, 98 Eur. Ct. H.R. (ser. A) (1986); Lithgow and Others v. United Kingdom, 102 Eur. Ct. H.R. (ser. A); Matos e Silva, Lda. and Others v. Portugal, Eur. Ct. H.R., Reports of Judgments and Decisions 1996-IV, 1114, § 86.

99. See Submission of the Quechan Indian Nation at 8, Glamis Gold v. United States of America, (NAFTA Ch.11 Arb. Oct. 16,2006), available at http://www.state.gov/documents/organization/75016 .pdf. Here, the potentially affected people by the investment project in question, a mine, asserted that they are protected by the 1966 International Covenant on Civil and Political Rights, the 1972 United 
ing values-investor protection and human rights-would take place on the international level and by international tribunals. The state may also use human rights as a defense for taking action against a foreign investor violating human rights under its duty to protect. Clearly, if a measure is taken in to order violating a norm of jus cogens, such as prohibitions on forced, compulsory, indentured, or other forms of slave-like labor, an investment tribunal would be bound to consider Article 53 of the Vienna Convention as applicable law. Furthermore, a state may defend itself by taking recourse to its duty to respect, protect, and fulfill its human rights obligations. ${ }^{100}$ That may involve taking measures against, or imposing regulations on, foreign investors. ${ }^{101}$ Nevertheless, states have rarely invoked their human rights obligations ${ }^{102}$ and therefore, they have not yet been considered extensively by tribunals, although there are some interesting cases pending.

One such case concerns issues of international human rights law in the field of race discrimination. In this case, Italian investors challenged the South African Black Economic Empowerment program as partially contained in the $2004 \mathrm{Min}$ eral and Petroleum Resources Development Act. ${ }^{103}$ They alleged that this affirmative action program for "historically disadvantaged individuals" infringes on their rights under the Italian-South African BIT, including national treatment. ${ }^{104}$

Nations Educational, Social, and Cultural Organization Convention on World Cultural Heritage, the International Labour Organization Convention on Indigenous and Tribal Peoples, and the InterAmerican Convention on Human Rights.

100. Asbjørn Eide had one of those duties in his capacity as Special Rapporteur on the Right to Food of the U.N. Sub-Commission on the Prevention of Discrimination and the Protection of Minorities. See Asbjørn Eide, Right to Adequate Food as a Human Right (1989); U.N. Econ. \& Soc. Council [ECOSOC], Sub-Comm'n on Prevention of Discrimination and Prot. of Minorities, Final Report "The Right to Adequate Food as a Human Right", U.N. Doc.E/CN.4/Sub.2/1987/23 (July 7, 1987) (prepared by Asbjørn Eide).

101. The European Court of Human Rights stated that states have the positive obligation to impose certain informational duties on firms which emit emissions dangerous to health under Art. 8 of the European Convention on Human Rights. See, e.g., Case of López Ostra v. Spain, 303 Eur. Ct. H.R. (ser. A) at 41 (1994); Case of Guerra and Others v. Italy, Eur. Ct. H.R., reprinted in REPORTS OF Judgments ANd Decisions 219 (1998).

102. To my knowledge, the only cases that have been decided until now concern the Argentinean crisis in which Argentina invoked the human rights obligations of its constitution, based on international human rights instruments. See CMS Gas Transmission Company v. Argentine Republic, ICSID (W. Bank) Case. No. ARB/01/08, II 114 (2005). The tribunal found that there was no conflict between investment protection and the constitution of A rgentina. Id. \115.

103. Piero Foresti v. Republic of South Africa, ICSID (W. Bank) Case No. ARB(AF)/07/1 (2007).

104. This is allowed under ECOSOC, Implementation of the International Covenant on Economic, Social and Cultural Rights General Comment No. 13, I 32, U.N. Doc. E/C.12/1999/10 (Dec. 8, 1999) ("The adoption of temporary special measures intended to bring about de facto equality for men 
This pending case will certainly give rise to principal issues of conflict not only between the BIT and Article 9 of the South African Constitution, but also under international human rights norms, such as those contained in the Convention on the Elimination of All Forms of Racial Discrimination ${ }^{105}$ and other provisions on discrimination in international human rights law. ${ }^{106}$

Other potential conflicts may arise in the area of privatized public services, such as water. Does international human rights law on the right to water ${ }^{107}$ need to be taken into account when adjudicating upon the host state's measures? What if, for example, a price cap or price differentiation is demanded ex post by governmental measures? What if there is a dispute on the contractual fulfillment by the investor, water "black outs" or contaminated water delivery? Similar issues were at stake in some cases already and more are expected to come up. ${ }^{108}$

Depending on how the contract is not performed in a public service concession, the state's duty to protect might be at stake; that is, it may be that it has to take certain regulatory measures in order to fulfill its international (and probably also constitutional) obligations. It may be required to do so by acting based on the precautionary principle, even if, ex post, there was no danger to health. ${ }^{109}$ Clearly, tribunals are

and women and for disadvantaged groups is not a violation of the right to nondiscrimination with regard to education, so long as such measures do not lead to the maintenance of unequal or separate standards for different groups, and provided they are not continued after the objectives for which they were taken have been achieved.").

105. Convention on the Elimination of All Forms of Racial Discrimination, G.A. Res. 2106A (XX), U.N. GAOR, Supp. No. 14, at 47, U.N. Doc A/6014 (Jan. 4, 1969).

106. For details, see Matthew Coleman \& Kevin Williams, South Africa's Bilateral Investment Treaties, Black Economic Empowerment and Mining: A Fragmented Meeting?, 9 Bus. L. INT'L. 56, 87-89 (2008).

107. The right to water is spelled out in U.N. Comm. on Econ., Soc. and Cultural Rights, General Comment No. 15: The Right to Water (Arts. 11 and 12 of the Covenant), U.N. Doc. E/C.12/2002/11 (Jan. 20, 2003).

108. Several cases involving water distribution and sewage services have been brought: Compañía de Aguas del Aconquija S.A. and Vivendi Universal v. Argentine Republic, ICSID (W. Bank) Case No. ARB/97/3 (2007); Azurix Corp. v. Argentine Republic, ICSID (W. Bank) Case No. ARB/01/12 (2006); BiwaterGauff (Tanzania) LTD. v. Tanzania, ICSID (W. Bank) Case No. ARB/05/22 (2008); Aguas del Tunari v. Boliva, ICSID (W. Bank) Case No. Arb/02/3 (2005). More than ten cases involving water services are pending, not all of them known. See Luke Eric Peterson, Int'L Inst. Sustainable Dev., Investment Treaty News: 2006-A Year in Review (2007).

109. That was at issue in the Vivendi case, where the water showed turbidity during approximately three months but posed no danger to human health. Vivendi, supra note 108, I 4.13. Nevertheless, the facts are such that for governments acting on precaution, some of the measures taken seem appropriate. 
aware that human rights issues are at stake ${ }^{110}$ and they have the interpretational freedom to take the human rights obligations of host states into account when adjudicating upon indirect expropriation, as well as fair and equitable treatment.

A further problem may arise in cases where indigenous rights are at stake, such as in natural resources extraction. "I' One pending North American Free Trade Agreement case illustrates this quite well. A California law ${ }^{112}$ requires the complete backfilling of open-pit mines near Native American sacred sites, including the site of a planned project by Glamis Gold, a Canadian investor who claims indirect expropriation. The Quechan Indian Nation, which claims that its religious sites are affected by the mining project, filed an amicus curiae brief, ${ }^{113}$ invoked Article 27 of the International Covenant on Civil and Political Rights. ${ }^{114}$ They, as well as the defendant, mention the relevance of several other international law instruments concerning cultural heritage. ${ }^{115}$

Here again, the question is whether the tribunal will also interpret the indi-

110. See Procedural Order No. 5, Biwater v. Tanzania, ICSID (W. Bank) Case No. ARB/05/22 (2007), http://icsid.worldbank.org/ICSID/FrontServlet? requestType =CasesRH \& actionVal =showDo c\&docId=DC532_En\&caseId=C67>; Order in Response to a Petition for Participation as Amicus Curiae, Aguas Provinciales de Santa Fe S.A., Suez, Sociedad General de Aguas de Barcelona S.A., and InterAguas Servicios Integrales del Agua S.A. v. Argentine Republic, ICSID (W.Bank) Case No. $\mathrm{ARB} / 03 / 17$, If 18 (2006) ("The factor that gives this case particular public interest is that the investment dispute centers around the water distribution and sewage systems of urban areas in the province of Santa Fe. Those systems provide basic public services to hundreds of thousands of people and as a result may raise a variety of complex public and international law questions, including human rights considerations. Any decision rendered in this case, whether in favor of the Claimants or the Respondent, has the potential to affect the operation of those systems and thereby the public they serve.").

111. A case that could have been a potential investment dispute was The Mayagna (Sumo) Awas Tingni Community v. Nicaragua, 2001 Inter-Am. Ct. H.R. (Ser. C) No. 79 (Aug. 31, 2001), where the government of Nicaragua granted logging concessions to logging firms on the territory of an indigenous tribe. If the government had been revoking those licenses (as it had to after the judgment) and the firms had been foreign investors protected by a BIT, the issue before an investment tribunal would have been clearly conflicting. For that decision, see S. James Anaya \& Claudio Grossman, The Case of Awas Tingni v. Nicaragua: A New Step in the International Law of Indigenous People, 19 ARIz. J. INT'L \& CoMp. L. 1 (2002).

112. S.B. 22, 2009-2010 Sess. (Ca. 2008); California State Mining \& Geology Board-Statutes and Regulations, http://www.conservation.ca.gov/smgb/regulations/Pages/regulations.aspx (last visited Feb. 22, 2009).

113. Quechan Indian Nation, supra note 99 , at 6.

114. International Covenant on Civil and Political Rights, G.A. Res 2200A (XXI), U.N. Doc. A/6316 (Dec. 16 1966).

115. Counter-memorial of the United States of America, Glamis Gold v. United States of America at 33, (NAFTA Ch. 11 Arb., Sept. 19, 2006), available at http://www.state.gov/documents/organization/ 73686.pdf (citing various international law instruments concerning cultural heritage). 
rect expropriation in the light of the international human rights instruments, especially norms protecting minorities and indigenous people, ${ }^{116}$ as well as the freedom of religion, thereby taking the purpose of the measure into account.

Nevertheless, investment tribunals have, thus far, been rather reluctant to include other special areas of PIL in the protective provisions of investment law. The tribunal in St. Elena v. Costa Rica ${ }^{117}$ held, in a dispute concerning the damages for expropriation for the purpose of erecting an environmental conservation area, that:

While an expropriation or taking for environmental reasons may be classified as a taking for a public purpose, and thus may be legitimate, the fact that the Property was taken for this reason does not affect either the nature or the measure of the compensation to be paid for the taking. That is, the purpose of protecting the environment for which the Property was taken does not alter the legal character of the taking for which adequate compensation must be paid. The international source of the obligation to protect the environment makes no difference. ${ }^{118}$

In SPP v. Egypt, ${ }^{119}$ a dispute over expropriation for cancellation of a tourism development project near the Egyptian pyramids, the tribunal held that the 1972 UNESCO Convention for the Protection of the World Cultural and Natural Heritage was relevant in principle, ${ }^{120}$ but not applicable in the present case because Egypt's international obligations under the Convention entered only into force after the investment had been concluded.

In sum, when interpreting investment treaties, international tribunals may take into account non-investment law through, Article 31(3)(c) of the Vienna Convention. If the protective norm of "fair and equitable treatment" is at stake, tribunals may balance the legitimate expectations of the investor with other noninvestment PIL, such as treaties concerning the environment or human rights. By

116. Also relevant to those kind of cases would be General Conference of the International Labour Organisation, June 27, 1989, Convention (No. 169) Concerning Indigenous and Tribal Peoples in Independent Countries, arts. 4, 5, 7. But it has been ratified by only seventeen countries and not by the United States. It could become relevant in other cases, though.

117. Compañia del desarollo de Santa Elena, S.A. v. Republic of Costa Rica, ICSID (W. Bank) Case. No. Arb. 96/1 (2000).

118. Id. II 71 (emphasis added).

119. Southern Pacific Properties (Middle East) Limited v. Arab Republic of Egypt, 19 Y.B. Сомм. Arb. 51 (1994).

120. Id. \ 78 . 
applying the proportionality principle, they may take into account the legitimate goals of such treaties (if host and home states are parties to the non-investment treaty) and scrutinize the measure taken by the host state by looking at its suitability and necessity. Here, much depends on the margin of appreciation given to the host state. Since this discussion is a very broad one and cannot be taken up here, it suffices to hint at the problem. A last test would also entail the proportionality striciu sensu. Here, the abstract weight and the concrete weight of the principles in question, for example, investor protection on the one hand and human rights issues on the other, come to the fore. Depending on what kind of human rights or environmental issues are at stake, it might well be that they have a greater abstract weight than investor protection. The tribunals would be asked to substantiate their arguments on this balancing better than most of them do now.

\section{Conclusion}

Institutional and normative fragmentation of international law is presumably here to stay with us for quite a while. The international legal system nevertheless strives for unity and coherence. Unless states mitigate the fragmentation problem through treaty-drafting, and unless there is hierarchy and non-fragmented adjudication, the problem of how to achieve substantive unity will continue. The means I have concentrated on is interpretation.

Systemic integration can be achieved through interpretation mainly through Article 31(3)(c) of the Vienna Convention. But the Vienna Convention tells us only which other international law can be considered when adjudicating. It does not tell us how to do it. The principle of proportionality, as a meta-principle of international law, is the most probable candidate for integration. It considers conflicting principles and harmonizes them through balancing.

The legal theoretical background of doing so has been elaborated by Robert Alexy. This allows for the consideration of other areas of PIL and helps to defragment PIL. Although measures taken by states and adjudicated by international courts and tribunals can be based on national constitutional law, the international law behind those principles (be it human rights or public goods) gives them extra force and weight in the balancing procedure. If the important principles of an international constitutional order cannot be reconciled through intra-constitutional problem-solving, the legitimacy of the diverse regimes in international relations might suffer. International courts and tribunals are thus burdened with a formidable task. 